УДК 792.077(=161.2):[343.818:341.34](438)]"1921”(045)

ORCID ID: 0000-0002-9098-1142

ORCID ID: 0000-0001-9750-4958

Паліснко Марина Геннадіївна, завідувачка кафедри архівознавства та спеціальних галузей історичної науки. Київський національний університет імені Тараса Шевченка, Київ

Maryna Paliienko, Head of the Department of Archival Studies and Special Historical Disciplines. Taras Shevchenko National University of Kyiv

Срібняк Ігор Володимирович, завідувач кафедри всесвітньої історії Київського університету імені Бориса Грінченка, Київ

Ihor Sribniak, Head of the Department of World History Borys Grinchenko Kyiv University

\title{
ОСОБЛИВОСТІ СТАНОВЛЕННЯ І РОЗВИТКУ НАЦІОНАЛЬНОГО ТЕАТРУ В ТАБОРАХ ІНТЕРНОВАНИХ ВОЯКІВ-УКРАЇНЦІВ АРМІЇ УНР У ПОЛЬЩІ, 1921 р.
}

Анотація. У статті проаналізовано процес становлення та розвитку українського національного театру в таборах інтернованих вояків-українців у Польщі впродовж 1921 р. У цей час театр залишався однією з найважливіших ланок культурно-освітньої та патріотично-виховної роботи в таборах, скріплюючи національно-державницькі прагнення інтернованого вояцтва. Таборовий театр став місцем, де інтерновані вояки-українці шукали і знаходили оригінальне вираження власним мистецьким пошукуванням, роблячи в такий спосіб свій внесок у скарбницю українського та європейського драматичного мистецтва.

Ключові слова: театр, трупа, драмгурток, репертуар, актор, табір, інтерновані вояки-українці, Польща.

Постановка проблеми та актуальність дослідження. 21 листопада 1920 р.- після відступу Армії УНР до меж Польської держави українські вояки були розміщені в кількох таборах (Пикуличі, Александрів, Вадовиці, Ланцут, Петроків, Каліш, Ченстохова) на становищі інтернованих. Хоча УНР і Польща були союзниками у нещодавній боротьбі з більшовицькою Росією, умови перебування українського вояцтва у більшості таборів спочатку були досить складними, що обумовлювалось непристосованістю дерев'яних бараків до тривалого в них перебування у зимовий час. Крім того, в таборах не було умов для організації дозвілля таборян, зокрема, тут бракувало приміщень, придатних для проведення масових культурно-мистецьких заходів. Ще однією проблему становила цілковита відсутність в українського командування коштів, потрібних для облаштування таких приміщень.
Але, попри всі ці труднощі, життя таборян поволі налагоджувалось, і насамперед це виявлялось у налагодженні культурно-мистецьких гуртків. Це пояснювалось тим, що таборяни найбільше потребували душевної розради в умовах перебування на чужині, а разом 3 тим - участь у постановці театральних вистав давала артистам можливість отримати певні кошти (завдяки надходженням від реалізації квитків на вистави). У свою чергу вищий політичний і військовий провід УНР добре усвідомлював нагальну потребу організації таборового дозвілля інтернованого вояцтва та членів їх родин.

Актуальність даної проблеми полягає у необхідності відтворення генези українського театру на чужині за майже повної відсутності умов для його поступального розвитку, а також встановлення ступеню його впливу на процес скріплення національно-патріотичного світогляду інтернованих у таборах Польщі вояків-українців Армії УНР. 
Аналіз останніх досліджень і публікацій. Попри те, що обставини перебування інтернованих вояків-українців Армії УНР у таборах Польщі $є$ сьогодні досить проясненими (Karpus, 1997; Срібняк, 1997; Колянчук, 2000), вивчення специфіки функціонування таборових театрів лише тільки починається (Срібняк \& Срібняк, 2018, с. 32-39; Срібняк \& Надтока, 2018, с. 108-115). Окремі прояви концертно-мистецької активності таборян знайшли своє відображення у документах, упорядкованих В. Моренцем у збірці «Армія за дротами» (2018), в якій зокрема були відтворені й окремі зразки програмок низки культурно-розважальних заходів (вечірок, концертів, театральних вистав) більшості таборів інтернованих українців у Польщі. Наукова розробка окремих аспектів діяльності таборових театрів триває й останнім часом, скажімо, одним з авторів даної статті був підготовлений окремий сюжет про діяльність драматичних товариств у таборі Стшалково (Срібняк, 2020 , c. $48-60)$.

Подана стаття підготовлена на основі залучення широкого кола архівних джерел, які були опрацьовані авторами у Центральному державному архіві вищих органів влади та управління України та двох архівосховищах Польщі. Це, зокрема, звіти культурно-освітніх відділів таборів, рапорти начальників груп інтернованих, протоколи засідань драматичних товариств, програмки театральних вистав, які виставлялись на сценах таборових театрів. Важливе значення для об'єктивного відтворення театрально-мистецького життя в таборах мають матеріали таборової преси, на шпальтах якої регулярно уміщувались оголошення про майбутні вистави, рецензії та них і навіть аналітичні оглядові статті про подальші шляхи розвитку українського театрального мистецтва.

Об'єктом пропонованого дослідження є український аматорський театр у таборах інтернованих вояків-українців Армії УНР у Польщі (1921р.), предметом - особливості його функціонування, репертуарна політика, а також аналіз діяльності режисерського і акторського складу таборових театрів. Mema cmammi полягає у розкритті особливостей становлення і розвитку національного аматорського театру в умовах таборової ізоляції українського вояцтва.

Виклад основного матеріалу. Перші паростки культурно-мистецького життя почали з'являтись у таборі Пикуличі (середина грудня 1920 р.), де при 1-й Кулеметній дивізії Армії УНР засновувалося самодіяльне театральне товариство, до складу якого були запрошені всі артисти-аматори табору. Вже за короткий час їх зусиллями на таборовій сцені було поставлено п'ять вистав, проведення яких було з ентузіазмом зустрінуте таборянами, які у цей час конче потребували душевної розради та спочинку. Як зазначалось в одній із заміток таборового часопису «Промінь» (це сталося вже після переїзду інтернованих до іншого табору), театр почав працювати в той момент, коли «більшість Українських вояків була пригнічена тою раптовою зміною < ..>> з менту військової катастрофи; коли майже всі вояки табору Пикуличі згубили надію на кращу будучину, коли кожний військовий, забувши про загальну мету, бачачи навкруги себе дроти й зарившись в свою нору і думаючи лише про себе» (Промінь а, 1921).

У співпраці з членами створеної дещо пізніше театральної секції таборового культурно-освітнього відділу та за сприяння начальника групи інтернованих Військ УНР в Пикуличах командувача 1-ї Запорізької стрілецької дивізії генерал-хорунжого Г. Базільського у таборі впродовж січня $1921 \mathrm{p}$. було підготовлено п’ять вистав («Мартин Боруля», «Батраки», «Сватання на Гончарівці», «Куди вітер віє», «Жартівниця» і «Хазяїн»), які були безоплатно запропоновані увазі таборового загалу (ЦДАВО України, ф.3526, оп.1, спр.1, арк.9). Задля створення сприятливих умов для роботи таборового театру основні його функціонери (головний режисер В. Далекий, режисер М. Салівон, сценарист О. Лютий, костюмер Хрущ, декоратор Гемпель) наказом начальника групи інтернованих були звільнені від виконання інших службових обов'язків [ЦДАВО України, ф.2439, оп.1, спр.189, арк.13]. Крім того, 3 метою відшкодування витрат на підготовку вистав та придбання реквізиту згадані п’єси «були повторені за плату» (ЦДАВО України, ф.3526, оп.1, спр.1, арк.9).

Але розбудувати роботу таборового театру на довший час у цьому таборі не видавалосz можливим, бо вже наприкінці лютого 1921 р. інтерновані були передислоковані з Пикуличів до інших таборів (Вадовиці та Ланцут). Особливо активним було театрально-мистецьке життя в таборі Ланцут, в якому приміщення для театру (ім. Т. Шевченка) облаштовувалось коштом інтернованих. Для цього начальником групи генералом Н. Никоновим був, зокрема, ініційований збір коштів (позичково) шляхом добровільних внесків від кожної окремої частини в таборі (ЦДАВО України, ф.2439, оп.1, спр.22, арк.60). Завдяки цьому стало можливим нарешті завершити у ньому всі роботи і провести 20 березня 1921 р. концерт на вшанування пам'яті Т. Шевченка (до 60 роковин його смерті) (ЦДАВО України, ф.4007, оп.1, спр.17, 31). 
Відкриття таборового театру також сприяло активізації роботи театральних аматорських осередків у таборі - при 1-й Кулеметній дивізії на чолі 3 сотником В. Далеким та при Збірній станиці на чолі 3 сотником Горуновичем (вже 31 березня ц. р. заходами драматичного гуртка 1-ї дивізії була виставлена п’єса «Хазяїн») (ЦДАВО України, ф.2439, оп.1, спр.24, арк.1043в.). Від самого початку існування ці два драмгуртки (драматичні товариства) проводили свою діяльність цілком самостійно. Ними ж була встановлена й вартість квитків на театральні вистави - 25 марок польських (м.п.), в якій були враховані всі видатки на підготовку вистав, включно з винагородою музикантам оркестру. Але й у цьому разі баланс драматичних товариств інколи зводився з дефіцитом - через те, що лише перша вистава була платною, а друга і третя (для старшин і козаків) - безкоштовними. Попри це, режисерам вдавалося все ж таки «зводити кінці з кінцями», a «театр мав успіх, даючи гарні п’єси в гарному виконанню артистів і в сценічному відношенні на тутешній сцені бездоганно» (Театрал, 1921, с. 41).

2 і 3 травня 1921 р. таборова трупа під керівництвом сотника В. Далекого поставила нову п'єсу «Сини народу». 3 цієї нагоди таборовий часопис «Промінь» опублікував статтю-рецензію одного з глядачів, в якій зазначалося, що деякі типажі цієї п'єси були виконані артистами «з особливою тонкістю і яскравістю». Таборові актори-аматори С. Якерсон, М. Салівон, Тимченко разом з режисером доклали всіх зусиль, аби передати глядачеві головну ідею цього твору. 5 травня таборова трупа під орудою Пашинковського вже втретє виставила п’єсу «Гаркуша», яка «зробила на глядачів приємне враження» (Театер і мистецтво а, 1921, с. 40).

Але така система організації діяльності драмгуртків не влаштувала новостворений культурно-освітній відділ табору на чолі з підполковником С. Тараном (ЦДАВО України, ф.2439, оп.1, спр.24, арк.275). Для розгортання своєї діяльності він конче потребував коштів, але штаб групи не мав можливості навіть мінімально йому допомогти в цьому. У цій ситуації начальник відділу вирішив перебрати на себе весь фінансовий бік театральної справи, «наклавши “лапу” на вільну творчість артистів, які працювали не для кишені, а для мистецтва, маючи на меті дати, скільки би це не коштувало з боку енергії, щось найкращого на тутешній сцені...». Спочатку наказом начальника культурно-освітнього відділу табору два драматичні товариства були об'єднані в єдину таборову театральну трупу акторів-аматорів у складі двох драмгуртків (при цьому реального об' єднання так і не відбулось), а ще за деякий час функціонерам культурно-освітнього відділу вдалося пересварити членів двох драматичних гуртків (Театрал, 1921, с. 41).

«Поправити» театральні справи мала скликана 5 травня 1921 р. комісія, до складу якої увійшов один представник від кожної окремої частини в таборі. Вона ухвалила рішення зменшити вартість квитків (до 5 м.п.), але при цьому санкціонувала скасування проведення безкоштовних вистав. Також було вирішено, що надалі всі артистичні сили, робітники сцени та музиканти працюватимуть безоплатно; квитки ж надалі мають реалізовуватись спеціально призначеним начальником культурно-освітнього відділу скарбником та надходитимуть до каси відділу.

Під час обговорення начальник культурно-освітнього відділу табору запропонував сотникові В. Далекому сформувати нову трупу, до якої мали увійти артисти, які були б готові грати безоплатно. Останній попередив, що якщо вояків ще можна було якось зобов'язати до участі у виставі, то таборове жіноцтво такі умови праці цілком би не влаштували. Понад те - сотник В. Далекий взагалі висловив сумнів у можливості утворення трупи внаслідок відсутності в ній жінок, у відповідь на що комісія пообіцяла йому залучити когось 3-поза табору, встановивши для цього місячну платню (5-7 тис. м. п.). Після цього комісія завершила свою роботу, щиро вважаючи, що «своєю постановою < .. > поставила театральну справу на певний шлях. Сувора ж дійсність виявила, що тут щось не так, що постанова комісії $є$ не поліпшенням театральної справи, а їі руйнуванням» (Театрал, 1921, с. 42).

Проте це унаочнилось тільки після 11 травня, коли ця ухвала набула чинності. До цього часу таборові артисти мали можливість провести вже заплановані вистави. 8 травня драматичний гурток Збірної станиці запропонував увазі таборян п’єсу «Борці за мрії» (режисер Горунович). Як зазначалось у таборовій газеті «Промінь», «із технічного боку п'єсу виконано бездоганно», проте «артистичне виконання не досягло належної висоти <..> мертво була проведена роля Калістрата, якій мусів передати характеристичні риси селянського духа». Один 3 акторів трупи - Пашинковський - «ролю вів так, що складалося вражіння, що він не грає, а відбуває обов'язок» (Театер і мистецтво а, 1921, c. 40-41). Ще через день драмгурток під орудою Пашинковського дав ще одну виставу - комедію «Пошились в дурні», яка хоч й потішала таборян, але не вирізнялась успішною акторською грою.

9 травня настала черга аматорів 3 драмгуртка 1-ї Кулеметної дивізії, які поставили «Куму Марту» (режисер - сотник В. Далекий). Цього разу 
«кадр артистів для п’єси був підібраний якнайліпше. Артисти крім того, що були у своїх ролях, ще й знали їх і грали з захопленням, через що й заслужили на похвали та бурю оплесків». Рецензент особливо наголошував ту обставину, що ця вистава справила на глядачів «величезне враження», тому на його думку - «бажано було би, щоби подібні п'єси частіше 3'являлись на нашій сцені у виконанні цего гуртка» (Театер і мистецтво а, 1921, c. $40-41)$.

Але після цієї вистави настала кількаденна перерва - режисер не зумів сформувати трупу, бо жоден $з$ драматичних гуртків не бажав розпорошувати свої сили та 3 кимось об'єднуватись. Відмовились увійти до трупи й жінки, які потребували хоча би мінімальних коштів для придбання гриму та паперу для розучування ролей. Заплановані на 13 i 14 травня вистави «Сини народу» не відбулись, хоча квитки на них вже були частково реалізовані (Промінь b, 1921, с. 48).

Культурно-освітній відділ вдався до чергових «маневрів», намагаючись, з одного боку, урухомити роботу драмгуртків та театру, а з іншого - продовжуючи претендувати на всі виручені за квітки кошти. Плата за квитки була знову збільшена, знову мали відбуватися безкоштовні вистави, а задіяним у виставах жінкам належалась «допомога». Ці «інновації» також не спрацювали, бо таборові актори були готові зрештою працювати безоплатно, але за умови, що з глядачів не братиметься плата за вхід на всі вистави.

Той порядок, який пропонував культурно-освітній відділ, був, на їх думку, абсолютно несправедливим, бо у той час, коли вони грали би на сцені безоплатно, «з публіки брали би гроші, й ці гроші будуть йти до чужої скриньки». Таким чином, за спиною артистів «хтось буде заробляти гроші, кудись їх витрачати», між тим останні не мали би на цей процес жодного впливу (Театрал, 1921, с. 42).

Отже, спроби організувати таборовий театр в Ланцуті на військових засадах, використовуючи при цьому мову наказів та розпоряджень - довели лише те, що організатори культурно-освітньої справи не мали жодного уявлення про специфіку драматичного ремесла. Фактично ними рухало лише бажання забезпечити надходження всіх без винятку виручених коштів за вистави на потреби культурно-освітнього відділу табору, начальник якого був би їх головним розпорядником.

Їхні хибні уявлення про те, що театром можна керувати як військовим підрозділом, були обумовлені браком гуманітарних знань у тих осіб, які призначалися штабом групи до організації проведення культурно-освітньої роботи, а також тією обставиною, що театр був добудований завдяки кільком грошовим внескам тих частин, які перебували в таборі, відтак - на думку командування групи - театр мав бути у «загальнотаборовій» власності. Вийти 3 цього «глухого кута», на переконання невідомого оглядача театральної дійсності в Ланцуті, можна було, коли до керівництва театральними справами в таборі прийшла би така людина, яка «сама була в шкірі аматора й професіонала» та добре розумілась би на цьому (Театрал, 1921, с. 42).

Після 11 травня 1921 р. у роботі таборового театру настала кількаденна перерва, що була зумовлена відмовою членів драмгуртків працювати на запропонованих таборовим культурно-освітнім відділом умовах. Вочевидь відповідальність за це цілком лягала на тих далеких від театрального мистецтва начальниках культурно-освітньої справи в таборі, а також і на генерала Н. Никонова, який призначав їх на ці відповідальні посади. Щоправда, в приміщенні театру таборові актори відчитали перед кількома сотнями перший випуск «живої таборової газети» «Промінь», що викликало жвавий інтерес присутніх тут таборян - від захоплення до критичних нападок на артистів, які не були авторами озвучених матеріалів (Промінь b, 1921, с. 44).

Все ж таки компроміс було знайдено - було вирішено, що для потреб культурно-освітнього відділу драмгуртками вноситиметься 7-10\% від чистого прибутку за кожну проведену платну виставу, про що можна довідатись із наказу № 3 штабу групи інтернованих від 4 червня 1921 р. (за підписом підполковника В. Чабанівського) про надходження для скарбника культурно-освітнього відділу табору різних сум (вісім виплат від 155 до 539 м. п. на загальну суму 2432 м. п.) за проведені театральні вистави (WBH CAW, sygn. I.380.13.7).

Завдяки цьому рішенню таборовий театр відновив свою роботу, i 21 травня драмгурток під орудою сотника Горуновича запропонував увазі таборян п’єсу Б. Грінченка «Нахмарило». Ця вистава, за оцінкою невідомого рецензента, опублікованою у таборовому часописові «Промінь», позначилась дещо слабкою грою самого Горуновича через його «апатичність» та якесь дивне відсторонення від того, що відбувалось на сцені. Рецензент пропонував для виконання таких ролей залучати «людей 3 більш рухливими рисами обличчя, щоб вони могли відбивати вразливість душі». Не зовсім вдалим, на його думку, був вибір для цієї вистави артисток, одна з яких не знала своєї ролі, «витримуючи цілі павзи (паузи - aвm.) між реченнями, що значить, що в павзах вона слухала репліки суфлера». Взагалі 
«було помітно, що всі квапились, а навіть суфлер, бо перекидав по дві сторінки п’єси», чим ледь не «пошив у дурні» деяких акторів (Театер і мистецтво b, 1921).

Наступного дня драмгурток під проводом сотника В. Далекого виставив на сцені таборового театру драму «Безробітні», весь чистий прибуток за яку призначався для ланцутської філії Українського Червоного Хреста (свою лепту в це внесли й таборові музиканти, які задовольнялись своїм половинним гонораром - 1000 м. п.) (Промінь с, 1921, с. 27). Актори-аматори впорались зі своїм завданням зразково, i «майже вся заля вкупі з артистами переживала ті тяжкі картини реального життя, реальної боротьби за добування щоденного шматка хліба», бо останнє було досить близьким таборянам (Театер і мистецтво b, 1921).

28 травня заходами драмгуртка відбулась прем'єра п'єси В. Винниченка «Панна Мара». На цю подію відразу ж відгукнувся таборовий часопис з рецензією авторства сотника Горуновича, який побажав колегам, аби «режисура надалі більш поважно поставилась до репертуару та не обмежувалась лише хламом, який $є$ у неї під руками». Він привітав постановку цієї п’єси, так само як і гру переважної більшості задіяних артистів-аматорів. Разом з тим він відзначив «дефекти» режисерської та акторської роботи під час вистави, вказавши зокрема на недостатню відпрацьованість комунікації між суфлером і артистами, цілком провальну гру одного з артистів (сотника Базилевича), якого краще було би «не випускати зовсім на сцену, бо він виявив нерозуміння типа, якого мусів дати, невміння триматися на сцені, а замість гри - одне фіглярство» (Горунович, 1921, с. 31-32).

3 цієї нагоди рецензент висловив своє нерозуміння тим, чому власне замість Базилевича не були задіяні присутні у трупі актори «з Божою гіскрою», віднісши до їх числа актора П. Касперта. Рецензент віддавав належне майже всім артистам за їх майстерну гру на сцені, а режисерові - за його «художню працю, що навіть кидалась у вічі і не знавцеві сцени по тим декораціям і обстановці ¥і1, не дивлячись на всю убогість театральних засобів» (Горунович, 1921, с. 32).

Цілком іншою була реакція рецензента на виставу «Живі покійники» Конич-Лисенка, яку було поставлено у таборовому театрі 31 травня. Найперше, що не сподобалось невідомому рецензентові - недосконалий переклад з російської та часте вживання артистами російськомовних фраз. На його думку, драмгурток переоцінив свої сили, ставлячи цю п’єсу, а невдале обсадження ролей артистками, одну з яких, був переконаний рецензент, - навіть «небезпечно випускати на сцену», бо остання неспроможна показати «ні гри, ні примітивного уміння ввічливо держатись [на сцені]». Єдиною світлою сторінкою вистави залишалась гра Пашинковського, який єдиний мав хист «доброго талановитого артиста» (Промінь d, 1921).

Наприкінці травня - на початку червня 1921 р. у таборовому театрі відбулися вистави п'єс «Кохайтеся чорнобриві, та не з москалями» (Театер i мистецтво b, 1921), «Нахмарило», «Невольник», «Живі покійники», «Заручені по смерті», «Жінка 3 того світу», «На межі», «Жидівка вихрестка» (ЦДАВО України, ф.2439, оп.1, спр.24, арк.276277). У цей час режисери таборових аматорських колективів докладали всіх зусиль для збагачення свого театрального репертуару — драмгурток 5-ї дивізії (колишньої 1-ї Кулеметної, яку було об'єднано 3 5-ю Херсонською) поставив п'єсу «Степовий гість» Б. Грінченка (19 і 21 червня), 20 і 22 того ж місяця - драмгурток Збірної станиці представляв виставу «Поки сонце зійде, роса очі виїсть» (друга вистава - безкоштовно) (ЦДАВО України, ф.2439, оп.1, спр.24, арк.250; WBH CAW, sygn. I.380.13.7; Семмо, 1921).

23 і 24 червня 1921 р. свої сили у лицедійстві випробували й члени козацького драматичного гуртка (WBH CAW, sygn. I.380.13.7), які запропонували увазі таборян три одноактівки («Бувальщина, або На чужий коровай очей не поривай» А. Велісовського, «Сусіди» («До мирового!») Л. Глібова і «По ревізії» М. Кропивницького) (Промінь е, 1921).

Поданий у наказі начальника штабу групи інтернованих «Реєстр вистав» свідчить про те, що таборовий театр (завідувач — полковник Я. Бальме) сповна виконував свою місію, пропонуючи таборянам вистави майже щодня. Лише впродовж 23 червня - 12 липня 1921 р. відбулися постановки п’єс: «Нахмарило», «Панна Мара», «Невольник», «Живі покійники», «Заручені по смерті», «Жінка 3 того світу», «На межі», «Кума Марта», «Жидівка-вихрестка», «Помста гуцула (WBH CAW, sygn. I.380.13.7). Виходячи лише з цього переліку можна зробити висновок, що в Ланцуті були зібрані кращі акторські сили інтернованої Армії УНР, зусиллями яких у здебільшого сумне дозвілля таборян вносились яскраві барви театрального мистецтва.

Ще одне місце інтернування українського вояцтва — табір у Вадовицях — теж мав кілька драмгуртків, які поперемінно пропонували увазі таборян різні п'єси українських драматургів. Роботі театру сприяло те, що йому надавалася вагома матеріальна допомога з боку YMCA*. Саме на кош- 
ти цісї організації у Вадовицях було облаштоване приміщення для театру.

На його сцені заходами драматично-співочої секції культурно-освітнього відділу 1-ї Кулеметної дивізії 27 липня 1921 р. були підготовлена до вистави одноактівки «По ревізії» М. Кропивницького i «Пропечатали» Тогобочного. 10 серпня ц.р. заходами згадуваної секції була поставлена п’єса «Мартин Боруля» на п’ять дій (для генералів Армії УНР секцією були навіть виготовлені окремі мистецьки оформлені запрошення) (ЦДАВО України, ф.4007, оп.1, спр.17, арк.18, 47-47зв., 48-48зв.).

12 серпня 1921 р. «збірними силами групи військ У. Н. Р.» було підготовлено театрально-співочу вечірку, до програми якої входили виступи хорів 1-ї Запорізької стрілецької та Окремої кінної дивізій, музичні номери у виконанні струнної оркестри Спільної юнацької школи, «деклямації і мельодеклямації» у виконанні різних артистів-аматорів та 3-й акт вистави «Запорожець за Дунаєм» (у виконанні драматичного гуртка Окремої кінної дивізії) (ЦДАВО України, ф.4007, оп.1, спр.17, арк.50, 51-51зв.).

Досить розбудованим (завдяки допомозі вже згадуваної ҮМСА) було культурно-мистецьке життя в таборі Александрів, де ще 20 грудня 1920 p. заходами Драматичного товариства імені М. Садовського був організований театральний гурток, до складу якого увійшли й артисти-аматори 4-ї Київської дивізії. У цей час - за згадками одного із організаторів культурно-мистецького життя в Александрові сотника М. Гладкого — «не було ні сцени, ні декорацій, ні костюмів, ні найголовнішого - не було ніяких засобів для того, щоби можна було молодому драматичному гурткові почати свою працю» (Гладкий, 1921, с. 17). Одначе організаційне становлення товариства тривало, завершившись 26 грудня ц.р. затвердженням його тимчасового статуту. В ньому була сформульована основна мета діяльності Драматичного товариства — «ознайомлення з рідною штукою (мистецтвом - aвm.) і дати розвагу інтернованим», задля чого члени товариства брали на себе зобов'язання популяризувати національне драматичне мистецтво та займатись артистичним самовдосконаленням (ЦДАВО України, ф.3523, оп.2, спр.1, арк.12; ЦДАВО України, ф.3526, оп.1, спр.3, арк.12).

Командування групи інтернованих знайшло можливість передати у розпорядження цього гуртка окремий барак, який належалось переобладнати у таборовий театр (на 400 місць). Значною проблемою для таборових артистів було облаштування сцени та виготовлення театральних костюмів, і тут їм на допомогу театру прийшла ҮMCA, яка надала грошову субвенцію театру (свій внесок у виготовлення декорацій та реквізиту зробило й Драматичне товариство імені М. Садовського) (ЦДАВО України, ф.2562, оп.1, спр.32, арк.108-108зв.).

Завдяки цій допомозі за перший місяць роботи таборового театру на його сцені були поставлені вистави «Пошились у дурні» М. Кропивницького і «Панна Мара» В. Винниченка, а також підготовлені ще кілька п’єс: «Зоря нового життя» А. Кащенка, «Мартин Боруля» I. Тобілевича, «Назар Стодоля» Т. Шевченка (Зірниця, 1921, с. 30). Надалі репертуар театру збільшився завдяки підготовці нових побутових та історичних п'єс українських авторів, у т.ч.: «Ой не ходи Грицю та на вечорниці», «Дай серцю волю- - заведе в неволю» (обидві - М. Кропивницького) та ін., але найбільшою популярністю у таборян користувались «Про що тирса шелестіла» С. Черкасенка i «Невольник» М. Кропивницького, а також кілька одноактних п'єс (Національно-освітня, 1921, cc. 29; 30, 2).

Важливим було й те, що з метою вдосконалення майстерності таборових акторів та задля ознайомлення їх з азами режисерської роботи у лютому-березні 1921 р. були організовані «театральні курси» (керівник - підполковник М. Блощаневич), на яких для 45-ти їх слухачів були проведені такі виклади, як «Історія театру», «Практичне гримування», «Теорія співу» та ін. (ЦДАВО України, ф.3523, оп.2, спр.1, арк.12; Зірниця, 1921, с. 30)

Готуючи вистави та безоплатно пропонуючи їх увазі глядачів, таборовий театр виконував важливу мобілізуючу функцію в таборі. Разом з тим, навіть коли за відвідування театру стягувалась невелика платня, чистий прибуток від частини таких вистав передавався на різні гуманітарні потреби самих таборян. Так, зокрема, всі виручені кошти від вистави п'єси «Невольник» М. Кропивницького (10325 м.п. від продажу вхідних квитків та програмок), яка відбулась 20 квітня 1921 р., були використані для поліпшення харчування хворих стрільців у таборі на Великодні свята (Хорому Стрільцеві, 1921, с. 4).

Ця ж вистава була повторена наступного дня, і таборовий часопис у короткій замітці-рецензії відгукнувся на майстерну гру акторів, якій була притаманна «підготовленість і упевненість у собі». Особливо було відзначено піднесену гру Блощаневича, Животівського і Агрес, які в останньому акті «особливо гарно і з мистецьким умінням» відтворили «сторінку страждань нашого народу в його тяглій боротьбі з ворогом у звичайній щоденності села» («Невольник», 1921, с. 4).

Загалом упродовж 1921 р. Драматичним товариством ім. М. Садовського було підготовлено близько 
50 вистав, 30 з яких відбулися безкоштовно - для мешканців табору. Завдяки роботі таборового театру та виступам хорових колективів вечірній час таборян був наповнений конструктивним змістом, здатним хоча би тимчасово тамувати ностальгічні відчуття інтернованих (ЦДАВО України, ф.2562, оп.1, спр.32, арк.108-108зв.).

Особливо сприятливі умови для свого розвитку мав таборовий театр у Каліші, для послуг якого ще в кінці грудня 1920 р. був обладнаний великий зал. Тоді ж утворився й т. зв. «гурток аматорів драми» (у складі 46 осіб), що діяв на підставі власного статуту. У переддень Нового року їх зусиллями на сцені таборового театру була поставлена п'єса «Бурлака» (ZniO, sygn. akc. 22.53.1), а 2 січня 1921 р. відбулась прем'єра вистави «Мартин Боруля» (у виконанні артистів-аматорів 2-ї Волинської дивізії») (Левицький, 1934, с. 2). I надалі таборові артисти-аматори тішили публіку постановкою нових п'єс, які зазвичай відвідували до 500 таборян (ЦДАВО України, ф.3525, оп.1, спр.1, арк.3). Наприкінці липня 1921 р. театральні гуртки Волинської та Залізної дивізій об'єднались у єдине Драматичне товариство ім. М. Садовського, що дало змогу піднести мистецький рівень вистав. Загалом упродовж 1921 р. калішськими трупами було підготовлено 25 вистав, деякі з яких виставлялися й поза табором - у місті Каліш (Срібняк \& Срібняк, 2018, с. 32-39; Срібняк \& Надтока, 2018, c. 108-115).

Влітку 1921 р. кількість таборів інтернованих українців була зменшена, а мешканців Александрова, Ланцуту й Вадовиць перевезено до Каліша, Щипіорно та Стшалкова. Зважаючи на таке ущільнення, у Стшалкові паралельно діяли п'ять самодіяльних театральних труп, що спричинилося до конкуренції між ними. Це мало на них радше позитивний вплив, оскільки змушувало акторіваматорів вдосконалювати свою майстерність. Одним з вагомих чинників такої їх стимуляції стала традиція критичного оцінювання вистав та розміщення суджень критиків майже про кожну виставу на шпальтах таборової «живої» газети «Промінь» (Срібняк, 2020, с. 48-60).

Висновки. Отже, наведений вище матеріал дає підстави для висновку про те, що таборовий театр завжди зберігав свою національну душу, розраджуючи таборян у скрутні хвилини їхнього безрадісного життя, наповнюючи їх повсякдення конструктивним сенсом. Увесь час театр залишався однією з найважливіших ланок культурно-освітньої та патріотично-виховної роботи в таборах, скріплюючи національно-державницькі прагнення інтернованого вояцтва. Разом з тим виступи таборових драматично-мистецьких колективів давали можливість хоча б на короткий час подумки перенестися до України, тамуючи їх ностальгію за власною домівкою та рідним краєм.

Попри всі складнощі перебування вояцтва в таборових умовах, які жодним чином не сприяли розвиткові його творчо-організаційної активності, на сцені таборового театру майже щоденно виставлялися п'єси, які належали до класики української та світової драматургії (відвідування більшості 3 них було безкоштовним для таборян). Переважна більшість вистав була національною за змістом та духом (всі без винятку п'єси готувалися до постановки українською мовою), сприяючи в такий спосіб духовній консолідації інтернованого вояцтва. Разом з тим, відвідування театру ушляхетнювало душі таборян, змушувало вкотре задуматись над складними питаннями соціального розвитку українського соціуму.

Майже у всіх таборах театр набував значення центру культурного життя усього таборового загалу, $з$ огляду на що інтерновані намагались усіляко підтримати мистецькі пошукування самодіяльних драматичних гуртків та товариств. Важливим було й те, що до підготовки вистав активно долучалося жіноцтво (дружини декого з таборян, які мали відповідні акторські здібності), що давало змогу надати відтворюваним у п'єсах подіям емоційності, гармонійності та реалістичності. Вагоме значення для таборових артистів мала й та обставина, що їх акторська робота винагороджувалась завдяки отримуваним прибуткам театральних труп від продажу вхідних квитків на деякі вистави в таборах та поза ï межами.

Крім усього іншого - український народний театр у таборах виконував місію «посла доброї волі» в Польщі, бо завдяки українській пісні, музиці, драматичному мистецтву серед польського суспільства закріплювалась позитивне сприйняття УНР та українців як частини європейського політичного та національно-культурного простору. Найголовнішим у цьому процесі було те, що таборяни шукали і знаходили оригінальне вираження власним мистецьким пошукуванням, роблячи в такий спосіб свій внесок у скарбницю українського та європейського драматичного мистецтва.

\section{Примітка}

* Young Men's Christian Association (Молодіжна християнська асоціація) - харитативна американська організація, яка надавала гуманітарну допомогу полоненим та інтернованим у таборах різних європейських країн. 


\section{Джерела та література}

Армія за дротами (2018). Збірка документів / редактор-упорядник В. Моренець. Кам'янець-Подільський. 432 с.

Гладкий Г. Театр Зірниця. Олександрів, 1921. 25 лютого. Ч. 3-4.

Горунович. Театер і мистецтво. Промінь. Ланцут, 1921. 31 травня. Ч. 6.

Зірниия. Олександрів, 1921. 25 лютого. Ч. 3-4.

Колянчук, О. (2000). Украӥнська військова емігращія у Польщі (1920-1939). Львів. 276 с.

Левицький В. В «союзницьких» таборах для полонених та інтернованих. Свобода. Джерсі-сіті, 1934. 25 вересня. Ч. 224.

Національно-освітня та військова праця в 4 Київській дивізії. Альманах. Александрів Куявський, 1921. № 1.

Нове життя. Щипіорно, 1921. 26 грудня. № 97.

«Невольник» на таборовій сцені. Нове життя. Александрово, 1921. 24 квітня. № 41.

Промінь а, (1921, 9 жовтня). Стрілково (Стиалково). Ч. 20 (посторінкова пагінація відсутня).

Промінь b, (1921, 16 травня). Ланцут. Ч. 2. (посторінкова пагінація відсутня - авт.)

Промінь с, (1921, 19 травня). Ланцут. Ч. 3. (посторінкова пагінація відсутня - авт.).

Промінь d, (1921, 3 червня). Ланцут. Ч. 7 (посторінкова пагінація відсутня - авт.).

Промінь е, (1921, 26 червня). Ланцут. Ч. 9 (посторінкова пагінація відсутня - авт.).

Семмо О. Театр і мистецтво. Промінь. Ланцут, 1921. 26 червня. Ч. 9 (без посторінкової пагінації - aвm.).

Срібняк, I. (1997). Обеззброєна, але нескорена: Інтернована Армія УНР у таборах Польщі й Румунії (1921-1924 рр.). Київ-Філядельфія. 187 с.

Срібняк I. \& Срібняк М. (2018). «Змога пережити естетичну насолоду...» (діяльність театрально-мистецьких осередків у Калішському таборі інтернованих Військ УНР у Польщі, 1921-1923рр.) Арт-простір. Київ. № 3. C. 32-39.

Срібняк І.В. \& Надтока Г.М. (2018), 3-тя Залізна стрілецька дивізія Армії УНР у 1921 р.: просвітня та культурно-мистецька складова таборового повсякдення вояцтва Вісник Національної академії керівних кадрів культури і мистеитв. Київ. № 3. С. 108-115.

Срібняк I. (2020). Український аматорський театр у таборі інтернованих Військ УНР Стшалково, Польща очима театральних критиків, серпень 1921 - липень 1922 рр. (за матеріалами часопису «Промінь») Синопсис: текст, контекст, медіа. Київ, 2020. Т. 26. С. 48-60.

Театер і мистецтво а, Промінь. Ланцут, 1921. 13 травня. Ч.1.

Театер і мистецтво b, Промінь. Ланцут, 1921. 23 травня. Ч. 4 (посторінкова пагінація відсутня - aвm.).

Театрал. Театральні справи. (1921, 16 травня) Промінь. Ланцут. Ч. 2.

Хорому Стрільцеві Нове життя. Александрово, 1921. 24 квітня. № 41.

ЦДАВО України, (Центральний державний архів вищих органів влади та управління України), ф.3526, оп.1, спр.1.

ЦДАВО України, ф.2439, оп.1, спр.189.

ЦДАВО України, ф.2439, оп.1, спр.22.

ЦДАВО України, ф.4007, оп.1, спр.17.

ЦДАВО України, ф.2439, оп.1, спр.24.

ЦДАВО України, ф.3523, оп.2, спр.1.

ЦДАВО України, ф.3526, оп.1, спр.3.

ЦДАВО України, ф.2562, оп.1, спр.32.

ЦДАВО України, ф.3525, оп.1, спр.1.

Karpus, Z. (1997). Jeńcy i internowani rosyjscy i ukraińscy na terenie Polski w latach 1918-1924. Toruń. 209 s.
Wojskowe Biuro Historyczne. Centralne Archiwum Wojskowe (WBH CAW). Zespól Akt «Sprzymierzona Armia Ukraińska» (SAU), sygn.I.380.13.7.

Zakład Narodowy im. Ossolińskich we Wrocławiu (ZniO), Dz. Rękopisów, sygn. akc. 22.53.1.

\section{References}

Armiia za drotamy [Army behind bars]. (2018). Zbirka dokumentiv / redaktor-uporiadnyk V. Morenets, KamianetsPodilskyi, 432 p. [in Ukrainian].

Hladkyi, H. (1921, 25 liutoho). Teatr [Theater], Zirnytsia [Dawn], Oleksandriv, 3-4. [in Ukrainian].

Horunovych. (1921, 31 travnia). Teater i mystetstvo [Theater and art], Promin [Beam], Lantsut, 6. [in Ukrainian].

Zirnytsia [Dawn]. (1921, 25 liutoho). Oleksandriv, 3-4. [in Ukrainian].

Kolianchuk, O. (2000). Ukrainska viiskova emihratsiia u Polshchi (1920-1939) [Ukrainian military emigration to Poland (19201939)], Lviv. [in Ukrainian].

Levytskyi, V. (1934, 25 veresnia). V «soiuznytskykh» taborakh dlia polonenykh ta internovanykh [In «allied» camps for prisoners and internees], Svoboda [Freedom], Dzhersi-siti, 224. [in Ukrainian].

Natsionalno-osvitnia ta viiskova pratsia $\mathrm{v} 4$ Kyivskii dyvizii [National-educational and military work in the 4th Kyiv Division]. (1921). Almanakh [Almanac]. Aleksandriv Kuiavskyi, 1. [in Ukrainian].

Nove zhyttia [New life]. (1921, 26 hrudnia). Shchypiorno, 97. [in Ukrainian].

«Nevolnyk» na taborovii stseni [«Slave» on the camp stage]. (1921, 24 kvitnia). Nove zhyttia [New life], Aleksandrovo, 41. [in Ukrainian].

Promin a. [Beam] (1921, 9 zhovtnia). Strilkovo (Stshalkovo), 20. [in Ukrainian].

Promin b. [Beam] (1921, 16 travnia). Lantsut, 2. [in Ukrainian].

Promin c. [Beam] (1921, 19 travnia). Lantsut, 3. [in Ukrainian].

Promin d. [Beam] (1921, 3 chervnia). Lantsut, 7. [in Ukrainian].

Promin e. [Beam] (1921, 26 chervnia). Lantsut, 9 [in Ukrainian].

Semmo, O. (1921, 26 chervnia). Teatr i mystetstvo [Theater and art], Promin [Beam], Lantsut, 9. [in Ukrainian].

Sribniak, I. (1997). Obezzbroiena, ale neskorena: Internovana Armiia UNR u taborakh Polshchi y Rumunii (19211924 rr.) [Disarmed, but unconquered: The interned Army of the Ukrainian People's Republic in the camps of Poland and Romania (1921-1924)], Kyiv-Filiadelfiia. [in Ukrainian].

Sribniak, I. \& Sribniak, M. (2018). «Zmoha perezhyty estetychnu nasolodu...» (diialnist teatralno-mystetskykh oseredkiv u Kalishskomu tabori internovanykh Viisk UNR u Polshchi, 1921-1923 rr.) [«The ability to experience aesthetic pleasure...» (the activities of theatrical and artistic centers in the Kalisz camp of interned troops of the UPR in Poland, 1921-1923)], Art-prostir [Art space], Kyiv, 2018, 3, pp. 3239. [in Ukrainian].

Sribniak, I. \& Nadtoka, H. (2018). 3-tia Zalizna striletska dyviziia Armii UNR u 1921 r.: prosvitnia ta kulturno-mystetska skladova taborovoho povsiakdennia voiatstva [3rd Iron Rifle Division of the Army of the Ukrainian People's Republic in 1921: educational and cultural-artistic component of the camp everyday life of the army], Visnyk Natsionalnoi akademii kerivnykh kadriv kultury i mystetstv [Bulletin of the National Academy of Management of Culture and Arts], Kyiv, 3, pp. 108-115. [in Ukrainian].

Sribniak, I. (2020). Ukrainskyi amatorskyi teatr u tabori internovanykh Viisk UNR Stshalkovo, Polshcha ochyma teatralnykh krytykiv, serpen 1921 - lypen 1922 rr. (za materialamy chasopysu «Promin») [Ukrainian amateur theater in the camp of interned troops of the Ukrainian People's 
Republic Strzalkowo, Poland through the eyes of theater critics, August 1921 - July 1922 (according to the magazine «Ray»)], Synopsys: tekst, kontekst, media [Synopsis: text, context, media], Kyiv, 2020, 26, pp.48-60. [in Ukrainian].

Teater i mystetstvo a. [Theater and art] (1921, 13 travnia). Promin [Beam], Lantsut, 1. [in Ukrainian].

Teater i mystetstvo b. [Theater and art] (1921, 23 travnia). Promin [Beam], Lantsut, 4. [in Ukrainian].

Teatral. (1921, 16 travnia). Teatralni spravy [Theatrical affairs], Promin [Beam], Lantsut, 2. [in Ukrainian].

Khoromu Striltsevi [To the sick shooter]. (1921, 24 kvitnia). Nove zhyttia [New life], Aleksandrovo, 41. [in Ukrainian].

CDADO Ukrainy, fond 3526, opys 1 , sprava 1.

CDADO Ukrainy, fond 2439, opys 1, sprava 189.

CDADO Ukrainy, fond 2439, opys 1, sprava 22.

CDADO Ukrainy, fond 4007, opys 1, sprava 17.
CDADO Ukrainy, fond 2439, opys 1, sprava 24.

CDADO Ukrainy, fond 3523 , opys 2, sprava 1.

CDADO Ukrainy, fond 3526, opys 1, sprava 3.

CDADO Ukrainy, fond 2562, opys 1, sprava 32.

CDADO Ukrainy, fond 3525, opys 1, sprava 1.

Karpus, Z. (1997). Jeńcy i internowani rosyjscy i ukraińscy na terenie Polski w latach 1918-1924 [Russian and Ukrainian prisoners of war in Poland in the years 1918-1924], Torun. [in Polish].

Wojskowe Biuro Historyczne. Centralne Archiwum Wojskowe (WBH CAW) [Military Historical Bureau. Central Military Archives]. Zespól Akt «Sprzymierzona Armia Ukraińska» (SAU), sygn. I.380.13.7.

Zakład Narodowy im. Ossolińskich we Wrocławiu (ZniO) [National Institute Ossoliński in Wrocław], Dz. Rękopisów, sygn. akc. 22.53.1.

\section{Maryna Paliienko, Ihor Sribniak \\ Establishment and development of the national theatre in camps for the UPR Army interned Ukrainians in Poland (1921)}

Abstract. The article analyzes the process of establishment and development of the Ukrainian national theatre in the camps for the interned Ukrainian soldiers in Poland during 1921. At that time, the theatre remained an essential nexus of cultural, educational, patriotic, and disciplinary work in camps that consolidated interned soldiers' national and state aspirations. Camp theatre became the place where interned Ukrainians searched and found creative expression of their own artistic ingenuity that substantially contributed to the treasury of Ukrainian and European dramatic arts.

Key words: theatre, theatre company, drama club, repertoire, actor, camp, interned Ukrainian soldiers, Poland. 